\title{
Comparative depth distribution of corallimorpharians and scleractinians (Cnidaria: Anthozoa)
}

\author{
Daphne G. Fautin ${ }^{1, *}$, John M. Guinotte ${ }^{2}$, James C. Orr ${ }^{3}$ \\ ${ }^{1}$ Department of Ecology and Evolutionary Biology, and Natural History Museum and Biodiversity Research Center, \\ University of Kansas, Lawrence, Kansas 66045, USA \\ ${ }^{2}$ Marine Conservation Biology Institute, 2122 112th Ave NE, Suite B-300, Bellevue, Washington 98004, USA \\ ${ }^{3}$ Marine Environment Laboratories (MEL-IAEA), 4, Quai Antoine 1er, MC-98000 Monaco, Monaco
}

\begin{abstract}
We assessed whether $\mathrm{CaCO}_{3}$ concentration of seawater may be relevant to the occurrence of members of Corallimorpharia and Scleractinia, which are very similar except for the possession by scleractinians of a calcareous skeleton. In collections of both the Challenger Deep-sea Expedition 1872-1876 and the US Antarctic (Research) Program, average depth of occurrence was significantly greater for corallimorpharians than for scleractinians. We also compared depth of occurrence relative to the position of the aragonite saturation horizon (ASH) at many localities from which specimens were collected. Nearly 25 and $50 \%$ of stations at which scleractinians were collected were below the ASH for the Antarctic and Challenger stations, respectively; 50 and $100 \%$ of the Antarctic and Challenger stations at which corallimorpharians were collected were below the ASH, respectively. Statistical analyses of these data to test whether there is a difference in the depth, relative to the $\mathrm{ASH}$, at which scleractinians and corallimorpharians occur indicate a difference for the Challenger but not the Antarctic stations; more data are needed. The scleractinians that tolerate living below the ASH belong to a minority of the genera recorded in the surveys, and do not include species considered important in forming bioherms; those that occur deepest are solitary. Some deep-sea scleractinians may be unaffected by shoaling of the ASH that is predicted across all ocean basins in the near future, some may be confined to water shallower than is now the case, and others may cease producing a skeleton, becoming morphologically indistinguishable from corallimorpharians.
\end{abstract}

KEY WORDS: Corallimorpharia $\cdot$ Scleractinia $\cdot$ Corals $\cdot$ Sea anemones

\section{INTRODUCTION}

Corallimorpharians (order Corallimorpharia) are anthozoans morphologically intermediate between sea anemones (order Actiniaria) and stony corals (order Scleractinia). Like a sea anemone, a corallimorpharian (Fig. 1) lacks a calcareous skeleton, but has internal morphology and nematocysts like those of a scleractinian (den Hartog 1980, Dunn 1982). Given concern that changes in seawater chemistry may affect the robustness of the skeletons of calcifying organisms or prevent formation of skeletons entirely (e.g. Orr et al. 2005, Kleypas et al. 2006, Guinotte \& Fabry 2008), we sought to compare the depth distribution of deep-sea coral- limorpharians with that of deep-sea scleractinians to infer if $\mathrm{CaCO}_{3}$ concentration may be relevant to the occurrence of these similar animals.

Corallimorpharia has far fewer members than the 2 groups to which it is most similar (45 valid species, compared with 1632 of Scleractinia and 1069 of Actiniaria; Fautin 2008). However, like scleractinians and actiniarians, corallimorpharians occur in all oceans, from polar to equatorial latitudes, and from the intertidal to at least $5 \mathrm{~km}$ in depth (actiniarians occur in the trenches as well). Shallow temperate and deep-water corallimorpharians at all latitudes resemble scleractinian polyps (Fig. 1a), whereas most shallow tropical corallimorpharians do not, being leathery in texture with short tenta- 

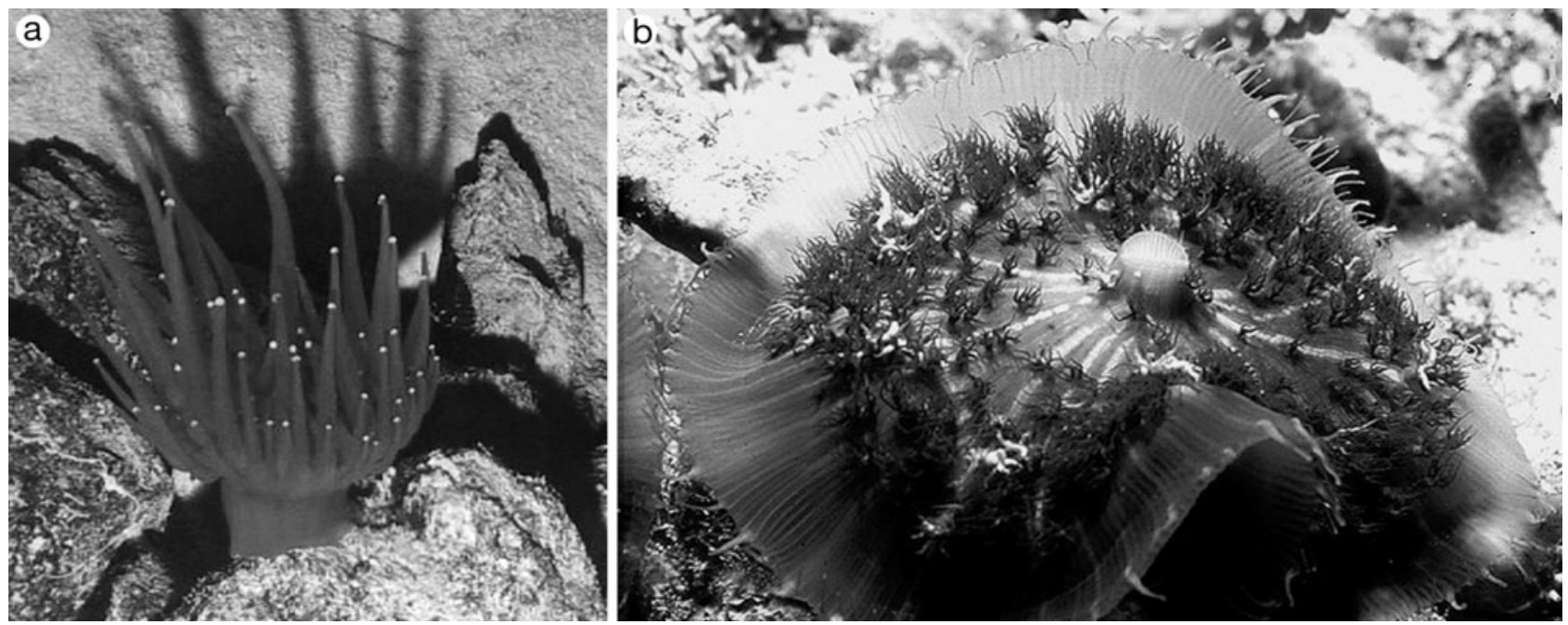

Fig. 1. (a) A deep-sea corallimorpharian, perhaps Corallimorphus pilatus, at $1798 \mathrm{~m}$ (photo from NOAA-HURL Archives, PI Amy Baco-Taylor). (b) A shallow tropical corallimorpharian (photo by G. Miller)

cles (Fig. 1b). Cogently, in our experience, people interested in and knowledgeable about deep-sea scleractinians may not recognize deep-sea corallimorpharians. Currently, Corallimorpharia occupies a rank identical to that of Actiniaria and Scleractinia, but during the past century it has been proposed (1) that they are really scleractinians lacking a skeleton and (2) that they belong with actiniarians (summarized by, inter alia, den Hartog 1980). Most recent molecular evidence supports Corallimorpharia as being separate from but more closely related to Scleractinia than to any other anthozoan group (Brugler \& France 2007, Fukami et al. 2008, earlier data summarized by Daly \& Fautin 2008). Regardless of phylogenetic details, corallimorpharians are more closely related to some corals than many of the groups referred to as 'corals' are to one another. Scleractinia and Corallimorpharia both belong to the anthozoan subclass Hexacorallia; some members of the other anthozoan subclass, Octocorallia, such as those of the family Isididae, are referred to as corals (e.g. Thresher et al. 2009).

To test whether deep-sea members of Corallimorpharia and Scleractinia differ in depth of occurrence, we compared collection records for members of the 2 taxa from comprehensive biological surveys that included data for both taxa. For 2 surveys that met our criteria, we found that, on average, corallimorpharians occur significantly deeper than scleractinians. Using data from the model of Orr et al. (2005) for carbonate saturation in seawater, we compared depth of occurrence with position of the aragonite saturation horizon (ASH) (the skeleton of a scleractinian is composed of $\mathrm{CaCO}_{3}$ in the crystal form aragonite). The outcome of our analyses concerning whether aragonite saturation of seawater can explain the difference in depth of occurrence of members of these taxa is ambiguous Although some scleractinian species can tolerate living below the $\mathrm{ASH}$, the ones collected deepest in both surveys were solitary. Guinotte et al. (2006) have shown that by the end of the 21st century, water at depths where $70 \%$ of deep-sea bioherm-forming scleractinians occur will be undersaturated with respect to aragonite. As a result of this shoaling of the ASH across all ocean basins in the immediate future, some scleractinians may be confined to water shallower than is now the case, and others may cease producing a skeleton. Ecosystem structure and function could be altered substantially with follow-on effects for organisms that depend on cold-water coral bioherms.

The number of records suitable for an analysis such as ours is small. The records we analyzed were from surveys not directed toward finding members of either taxon; data from surveys focused on documenting the occurence of members of one of the taxa could be biased. We are confident that all corallimorpharians collected on the 2 surveys were included in the data we analyzed. In addition to assessing whether depth of occurrence differs between members of these 2 anthozoan groups, an aim of the present study is to stimulate, by our provisional results, the acquisition of additional data to test further the hypothesis that $\mathrm{CaCO}_{3}$ concentration affects the occurrence of deep-sea scleractinians.

\section{METHODS}

We acquired occurrence records for scleractinians and corallimorpharians from 2 biological surveys: the Challenger Deep-sea Expedition 1872-1876 (e.g. 
Rehbock 1992, Langmuir 2004, Perry \& Fautin 2004) and the US Antarctic Research Program (USARP; now termed the US Antarctic Program) as assembled in the online resource 'Hexacorallians of the World' (Fautin 2008). To obtain the data used, on the opening page of 'Hexacorallians of the World' (http://hercules.kgs. ku.edu/Hexacoral/Anemone2) select 'Distributional Data,' then successively select from the list of menus 'Expedition' and 'Name.' When an expedition name is selected from the pick list or typed into the search box, a map of the stations for that expedition appears, and a list of specimens from that expedition can be selected to display. Records can be downloaded in XML.

In our analyses, we used the names published in the data sources except for the few cases in which the same specimen was referred to a different genus in a subsequent publication; in these we referred the species to the genus in which it was most recently placed. Although all published records we used are vouchered by museum specimens, we did not examine the specimens themselves.

The 50 volumes that constitute the results of the Challenger Expedition include 2 chapters on scleractinians, one by Moseley (1881) on deep-sea corals and one by Quelch (1886) on shallow-water, reef-building corals. Although most specimens dealt with in the chapter by Quelch (1886) seem to have been collected by shore parties, members of 5 species were collected at one numbered sampling station 8 fathoms deep. Because those specimens occurred in such shallow water and were recorded nowhere else in the Challenger Expedition reports, we did not include any data from Quelch (1886) in our analysis. The data in a preliminary report by Moseley (1876) are included in the later report (Moseley 1881), but since publication of the formal results, additional specimens collected on the Challenger Expedition have been identified. Our analyses include those in publications by Cairns \& Zibrowius (1997) and Cairns et al. (2005); we do not include those by Brook (1892) because they concern shallow-water species and lack station numbers, from which we infer that they were taken in shore collections.

Our analyses include all published records of corallimorpharians from the Challenger Expedition. Hertwig $(1882 a, b, c, 1885,1888)$ inventoried the Challenger sea anemones sensu lato (members of orders Actiniaria and Corallimorpharia), but in a short paper, Moseley (1877) described the 2 species of corallimorpharians included by Hertwig $(1882 \mathrm{a}, \mathrm{b})$. Hertwig (1888) described a third species of corallimorpharian from the Challenger Expedition.

Most of the occurrences in the Antarctic and subAntarctic we analyzed were for specimens collected under the auspices of the USARP in the 1960s and 1970s using the ships 'Eltanin', 'Hero', and 'Islas
Orcadas'. The publication documenting scleractinians was written by Cairns (1982) and that on corallimorpharians was written by Fautin (1984).

We compared depth of occurrence for scleractinians versus corallimorpharians collected on the Challenger Expedition and under the auspices of the USARP. Our analysis was based solely on presence at a station; we did not consider the number of individuals sampled. The significance of the differences we found was assessed with the Mann-Whitney $U$-test, a non-parametric statistic equivalent to the parametric $t$-test. For all statistical tests, we accepted as significant $\mathrm{p}$-values less than $5 \%$.

We compared the depth of each station at which at least one specimen was collected to the ASH at that location for the subset of stations for which ASH data were available. Values for ASH depth are based on the model outputs described by Orr et al. (2005); modeled ASH data are lacking for some enclosed regions, including the Weddell and Ross Seas. Modeled data are available for the years 1765 and 1994; for the stations where data for both years are available, our results were identical, but we used the 1994 data because only they are available for some stations. To determine if the proportion of stations below the ASH at which corallimorpharians were collected differed from the proportion at which scleractinians were collected, we used Fisher's exact test (a statistic that is more accurate than the chi-squared test when expected values are small).

\section{RESULTS}

Fig. 2 plots the Challenger stations from which corallimorpharians and scleractinians were collected, and Fig. 3 plots the Antarctic and sub-Antarctic localities. Table 1 presents comparative data for the animals collected by the Challenger, and Table 2 for those collected in Antarctic and sub-Antarctic waters. The value for the Mann-Whitney $U$-test assessing the null hypothesis that scleractinians and corallimorpharians for the 2 data sets combined occur at equal depth was $\mathrm{p}=0.00003$ for 1 -tailed and 0.00006 for 2-tailed.

Table 3 presents occurrence data for scleractinians and corallimorpharians from those Challenger and Antarctic and sub-Antarctic stations for which modeled ASH data exist. For Scleractinia, the number of genera to which those species belong is also shown as a proportion of the total number of genera in the data set (all corallimorpharians belong to Corallimorphus). ASH data were available for 159 localities for scleractinians (40 Challenger stations, 119 Antarctic and sub-Antarctic stations) and 15 for corallimorpharians (5 Challenger stations, 10 Antarctic and sub-Antarctic 


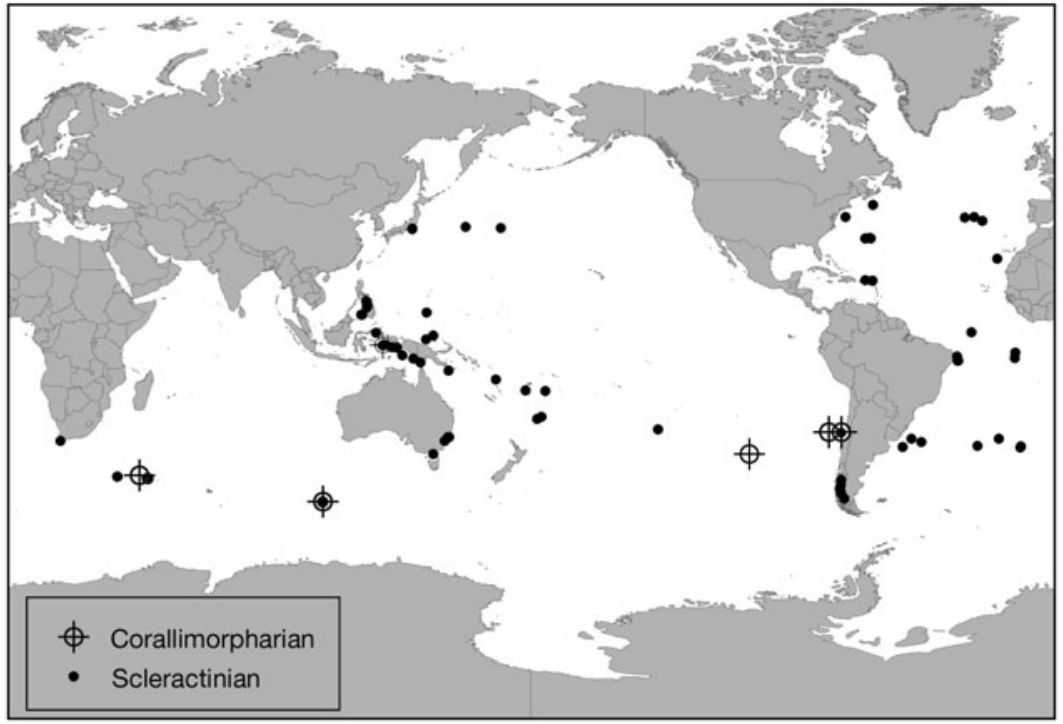

Fig. 2. Challenger Expedition stations from which corallimorpharians and scleractinians were collected

stations). For the Challenger Expedition, ASH data were available for 5 of the 6 stations at which corallimorpharians were collected and 40 of the 71 stations at which scleractinians were collected. For the Antarctic, ASH data were available for 10 of the 12 stations at which corallimorpharians were collected and for 119 of the 187 stations at which scleractinians were collected.

Average depth of occurrence was calculated for the 20 Antarctic species for which we had 3 or more records (69 for Flabellum impensum). The values were rather continuous from $62 \mathrm{~m}$ (5 records for Sphenotrochus gardineri, range 9 to $116 \mathrm{~m}$ ) to $757 \mathrm{~m}$ (3 records for Enallopsammia rostrata, range 333 to $1028 \mathrm{~m}$ ). The 4 species with the deepest average depths of occurrence were Flabellum apertum ( 7 records, mean $971 \mathrm{~m}$, range 587 to $1647 \mathrm{~m})$, Flabellum truncum (4 records, mean $1333 \mathrm{~m}$, range 587 to $1896 \mathrm{~m})$, Fungiacyathus marenzelleri (10 records, mean $2056 \mathrm{~m}$, range 300 to $4840 \mathrm{~m}$ ), and Leptopenus antarcticus (5 records, mean $2182 \mathrm{~m}$, range 2005 to $2384 \mathrm{~m}$ ); the 4 deepest records were of Fungiacyathus marenzelleri (mean $3598 \mathrm{~m}$, range 2836 to $4840 \mathrm{~m}$ ). For the Challenger data, only 3 species were recorded at 3 or more stations: Desmophyllum ingens (3 records, mean $341 \mathrm{~m}$, range 256 to $448 \mathrm{~m}$ ), Solenosmilia variabilis (3 records, mean $654 \mathrm{~m}$, range 256 to $768 \mathrm{~m}$ ), Bathyactis symmetrica (14 records, mean $3196 \mathrm{~m}$, range 1829 to $5304 \mathrm{~m})$. According to Cairns (1982), some, but not all, of the Challenger records under the name Bathyactis symmetrica refer to Fungiacyathus marenzelleri; the name B. symmetrica has been applied to 5 species, all members of the genus Fungiacythus (Fautin 2008).

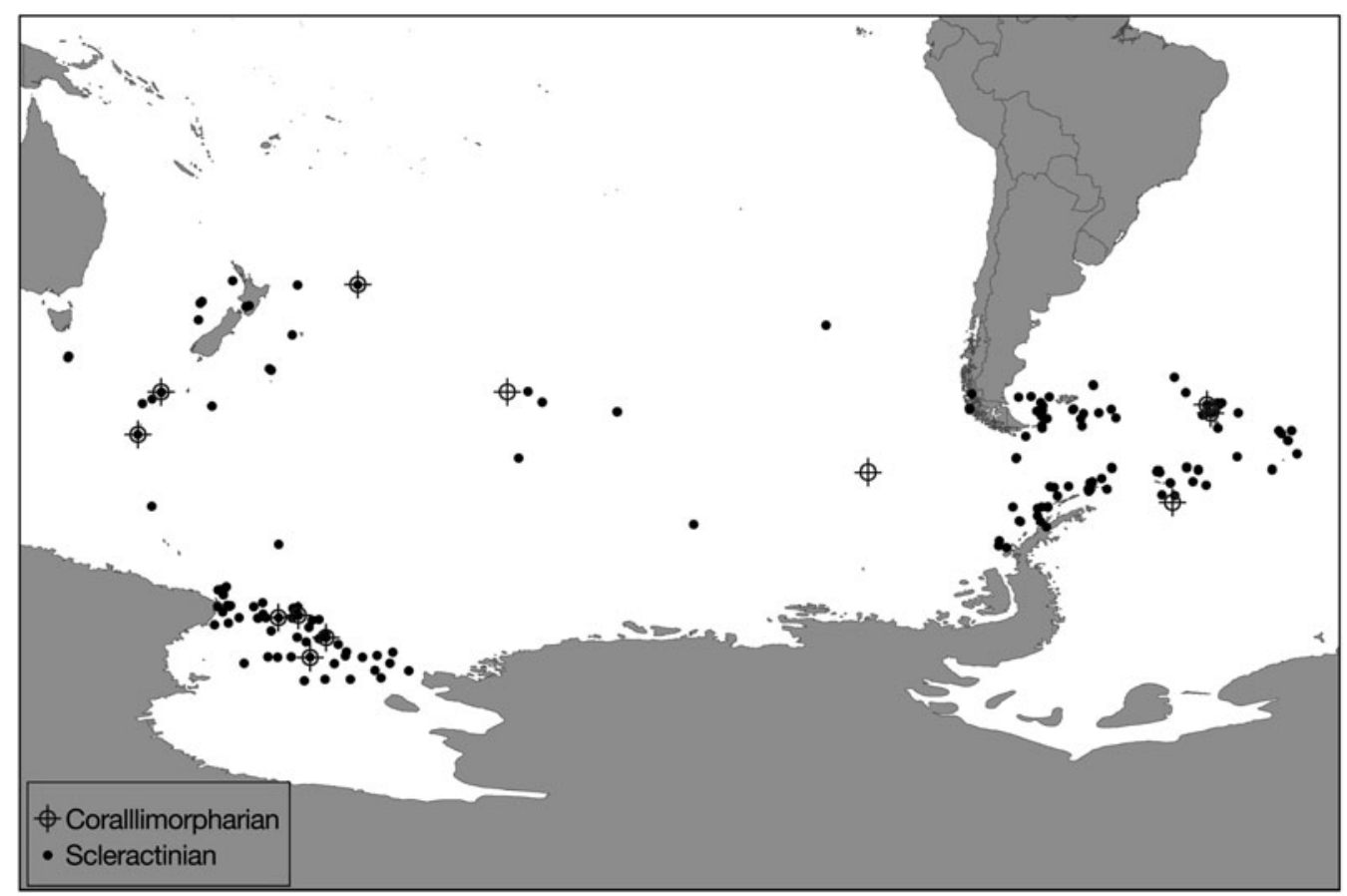

Fig. 3. Antarctic and sub-Antarctic stations from which corallimorpharians and scleractinians were collected 
Table 1. Comparison of scleractinians and corallimorpharians collected by the Challenger Expedition. The values for the MannWhitney $U$-test assessing the null hypothesis that Challenger scleractinians and corallimorpharians occur at equal depth are $\mathrm{p}=0.003883$ for 2 tails and $\mathrm{p}=0.001942$ for 1 tail

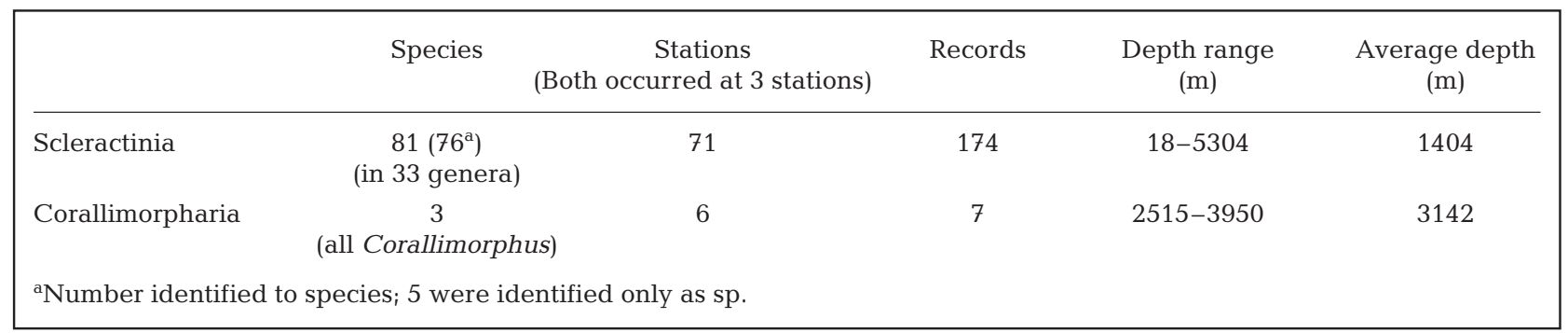

Table 2. Comparison of scleractinians and corallimorpharians collected in the Antarctic and sub-Antarctic mainly under the auspices of the US Antarctic Research Program. The values for the Mann-Whitney $U$-test assessing the null hypothesis that Antarctic and sub-Antarctic scleractinians and corallimorpharians occur at equal depth are $\mathrm{p}=0.00584$ for 2 tails and $\mathrm{p}=0.00292$ for 1 tail

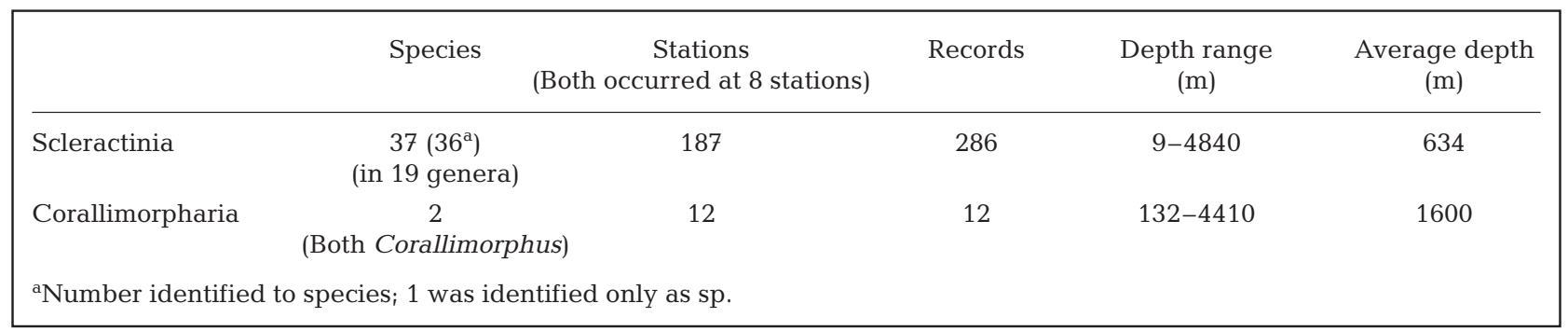

Table 3. Proportion of stations for which there are data on the aragonite saturation horizon ( $\mathrm{ASH}_{\text {; }}$ as of 1994) where scleractinians and corallimorpharians were collected deeper than the ASH. 'Stations' refers to the proportion of stations at which members of each taxon were collected that were deeper than the ASH (regardless of the number of species reported at that station). 'Species' refers to the portion of species reported from at least 1 station deeper than the ASH (regardless of whether other specimens of the species were reported from depths shallower than the ASH). The denominator is the total number of species in the data set (as shown in Tables 1 \& 2). The null hypothesis for Fisher's exact test was that there is no difference in the proportion of stations below the ASH from which scleractinians and corallimorpharians were collected

\begin{tabular}{|lccc|}
\hline Surveys & Scleractinia & Corallimorpharia & $\begin{array}{c}\text { Fisher's exact } \\
\text { test }(\mathrm{p})\end{array}$ \\
\hline Challenger & & & \\
Stations & $18 / 40(45 \%)$ & $5 / 5(100 \%)$ & 0.028 \\
Species & $42 / 81(52 \%)$ & $3 / 3(100 \%)$ & \\
\multicolumn{4}{c}{ in $9 / 33(27 \%)$ genera } \\
Antarctic and sub-Antarctic & & 0.119 \\
Stations & $27 / 119(23 \%)$ & $5 / 10(50 \%)$ & \\
Species & $15 / 37(41 \%)$ & $2 / 2(100 \%)$ & \\
Combined surveys & in $9 / 19(47 \%)$ genera & & 0.0063 \\
Stations & $45 / 159(28 \%)$ & $10 / 15(67 \%)$ & \\
\hline
\end{tabular}

\section{DISCUSSION}

The average depth at which corallimorpharians occurred was significantly greater than that for scleractinians $(p<0.01)$ in data from both the Challenger Expedition and the USARP, and for the 2 data sets combined, although the depth range of scleractinians exceeded that of corallimorpharians in both surveys (Tables 1 $\& 2)$. This may be a demonstration of the pattern of habitat partitioning in anthozoans identified by Fautin (1989). The Antarctic and sub-Antarctic are lower in diversity of both scleractinians and corallimorpharians, despite samples having been taken at more than twice as many Antarctic and sub-Antarctic stations as Challenger stations (Tables 1 $\& 2$ ). This is not surprising given that the Challenger sampled over $100^{\circ}$ of latitude, from $43.07^{\circ} \mathrm{N}$ (Stn 48, northwest Atlantic) to $64.3^{\circ} \mathrm{S}$ (Stn 153, southern Indian Ocean). Average depth of collection for both scleractinians and corallimorpharians is about half that in the Antarctic and sub-Antarctic as for the Challenger, supporting the idea of latitudinal submergence/emergence (e.g. Ekman 1953, Franz et al. 1981).

Because these animals are so similar except for the scleractinian aragonitic skeleton, we reasoned that saturation of seawater with respect to aragonite might be responsible for the difference in their depth of occurrence; $\mathrm{CaCO}_{3}$ in the seawater is presumably physiologically relevant for scleractinians but not for coral- 
limorpharians. Consistent with that hypothesis, the proportion of stations below the ASH at which corallimorpharians occurred was twice that for scleractinians. The differences in this proportion were significant for the Challenger data and all the data combined, but not for the Antarctic and sub-Antarctic data. Our findings are suggestive but not conclusive; further testing of the hypothesis that seawater chemistry is responsible for the clear difference in depth of occurrence of members of these 2 taxa requires additional data. More occurrence data for deep-sea corallimorpharians and scleractinians from unbiased sources, which are difficult to obtain, may help clarify the importance of seawater chemistry to the lives of animals of these taxa, and as models for carbonate saturation in seawater are refined and extended to places not now covered, the data we used can be reassessed.

Although it is widely held that scleractinians evolved from an anemone-like animal that developed a skeleton (e.g. Scrutton 1999), based on morphology, Hand (1966) suggested that sea anemones descended from scleractinians in a process that included loss of the skeleton. Likewise, a phylogeny using radioimmunoassay (Fautin \& Lowenstein 1994) found Scleractinia ancestral to both Corallimorpharia and Actiniaria. Veron (1995) proposed that the scleractinian skeleton has evolved and been lost repeatedly. In the detailed scleractinian phylogeny of Romano \& Cairns (2000), the calcareous skeleton was inferred to have evolved independently as many as 4 times. Medina et al. (2006) found corallimorpharians to be nested among scleractinians, which they interpreted as supporting the idea of lability of the skeleton. By contrast, Daly et al. (2003), Brugler \& France (2007), and Fukami et al. (2008) found Corallimorpharia to be the sister taxon to Scleractinia rather than being nested within Scleractinia. Contrary to the assertion by Fukami et al. (2008), the topology of Corallimorpharia as the sister taxon to Scleractinia rather than being nested within Scleractinia does not, in itself, logically refute the 'naked coral hypothesis' (e.g. Fautin \& Lowenstein 1994, Stanley \& Fautin 2001), which holds that the skeleton exists under conditions of favorable seawater chemistry and disappears when conditions become unfavorable. Although the most parsimonious explanation may appear to be that the skeleton arose in the common ancestor of Scleractinia after the branch point with Corallimorpharia, if time is taken into consideration, as it was by Fautin \& Lowenstein (1994) and Medina et al. (2006), that branch arose at a time when scleractinians existed, as attested to by fossils. None of these phylogenetic analyses included deep-sea corallimorpharians.

Evidence is growing that some scleractinians can survive without their skeletons. Goreau \& Goreau (1959, p. 247-248) reported that 'polyps of starving corals [taxon not specified] are able to detach themselves completely from the corallum. In this phase they can stay alive for some weeks without showing any evidence of renewed skeletogenesis although they are able to ingest food normally.' Sammarco (1982, p. 57) coined the term 'polyp bail-out' for the abandonment of their skeleton by polyps of the scleractinian Seriatopora hystrix under stress, which he described as both an 'escape response' and a 'mode of asexual reproduction.' Sammarco (1982, p. 57), who observed this in the field and the laboratory, found that some polyps can secrete a new skeleton. Home aquarists have observed fleshy scleractinians crawl out of their skeletons (P. Alderslade pers. comm.); one can speculate that stress may cause such behavior. Although the skeleton presumably protects corals, skeletonless anthozoan polyps can survive in nature: witness the existence of corallimorpharians and sea anemones.

There is also experimental evidence that production of a coral's skeleton can be sensitive to $\mathrm{CaCO}_{3}$ saturation state. Fine \& Tchernov (2007) demonstrated that under conditions of low $\mathrm{pH}$, the skeleton of 2 species of scleractinians dissolved, and the animals, although ceasing to deposit a skeleton, persisted. Moreover, the polyps separated physically, as Sammarco (1982) also found. Such 'naked' polyps are indistinguishable from corallimorpharians, which do not form colonies, although those of many or all species can propagate asexually and those of some species tend to live in clonal aggregations. When $\mathrm{pH}$ was increased, the animals resumed calcifying (Fine \& Tchernov 2007). Thus, the abandonment of its skeleton by fleshy corals in home aquaria might be stimulated by the low saturation state of $\mathrm{CaCO}_{3}$ that is typical of such aquaria. It is perhaps significant that the water in which Sammarco (1982) kept his corals, at the Australian Institute of Marine Science, came from offshore and was circulated in a flow-through system (P. W. Sammarco pers. comm.). Such seawater would be expected to be more saturated in $\mathrm{CaCO}_{3}$ than water used by home aquarists.

The similarity between some deep-sea corals and corallimorpharians has long been noted. In his remarks in the Challenger proceedings that accompanied the description of the new genus and species Corallimorphus profundus, Moseley (1877, p. 301) stated, 'Similar or kindred forms were often dredged in deep water by the 'Challenger.' They seem closely allied to the simple disk-shaped corals, such as Stephanophyllia, in which the tentacles are also knobbed and disposed at the margin, and on the surface of the disk, in a closely similar manner. They have further similar thread-cells [nematocysts] to these solitary corals, and, indeed, appear to differ from them only in having no calcareous corallum developed. Indeed, in one species of 
Stephanophyllia, obtained in deep water, the calcareous skeleton was in a most rudimentary condition, being a mere delicate network of calcareous trabeculæ. So like in appearance were these forms of Actininæ to the living corals, that it was only by feeling them as they were found in the dredge that I became convinced that they had no calcareous skeleton, and I macerated several in caustic potash in the hopes of finding traces of a corallum present in them. They seem to approach these disk-like corals very closely, and possibly to represent forms from which the corals were developed.'

Implicit in most discussions of the lability of the scleractinian skeleton is the idea that scleractinian taxa differ in sensitivity to $\mathrm{CaCO}_{3}$ concentration in seawater-so some may be unable to survive without a skeleton. Our data show that some scleractinians are capable of living well below the $\mathrm{ASH}$, and some appear to occur mainly or exclusively in relatively deep water (e.g. Fungiacyathus marenzelleri, Leptopenus antarcticus, and many species of Flabellum). However, most of the species included in our analyses do not form bioherms, and the species that occur the deepest - like those referred to by Moseley (1877) above - are solitary. Indeed, in our data, none of the 6 species considered by Guinotte et al. (2006) to be 'deep-sea bioherm-forming corals' occurred deeper than the ASH. Thus, we infer that colonial species will be especially affected by decreased $\mathrm{CaCO}_{3}$ saturation, either by being unable to persist in the altered waters or, as in the colonial species studied by Fine \& Tchernov (2007), ceasing to form a skeleton and losing tissue connection between polyps. The potential loss not only of skeletons but of coloniality with diminishing $\mathrm{CaCO}_{3}$ saturation has implications for ecosystems in which coral colonies provide structure, attachment surfaces, and refuges for hundreds of species.

Scleractinians that live in the deep sea may be physiologically adapted to harvest scarce ions effectively and/or their skeletons may be protected from the corrosive water by being covered by thick or unbroken tissue. Thus, although reduction of $\mathrm{CaCO}_{3}$ saturation in the near future will likely affect many scleractinians, it is unlikely to affect members of all taxa equally or in the same ways. Some may simply be unable to survive in water of diminished $\mathrm{CaCO}_{3}$ saturation, and so will be found shallower and shallower as time goes on; some may be able to persist as they are, and some may remain where they are but cease making a skeleton, and so be grossly indistinguishable from corallimorpharians.

Acknowledgements. Funding was provided by US National Science Foundation grant nos DEB95-21819 and DEB9978106 (Partnerships to Enhance Expertise in Taxonomy), OCE
00-03970, and EF-0531779 (Assembling the Tree of Life), and by grants from the Educational Foundation of America and ESRI to the Marine Conservation Biology Institute. S. Bokka assembled the data analyzed for this study. We thank S. Cairns for taxonomic advice, P. Sammarco for information about his observations, and J. Kelly and W. Eash-Loucks for help with statistics.

\section{LITERATURE CITED}

Brook G (1892) Preliminary descriptions of new species of Madrepora in the collection of the British Museum. Ann Mag Nat Hist Ser 6 10:451-465

> Brugler MR, France SC (2007) The complete mitochondrial genome of the black coral Chrysopathes formosa (Cnidaria: Anthozoa: Antipatharia) supports classification of antipatharians within the subclass Hexacorallia. Mol Phylogenet Evol 42:776-788

Cairns SD (1982) Antarctic and sub-Antarctic Scleractinia. Antarct Res Ser 34:1-74

Cairns SD, Zibrowius H (1997) Cnidaria Anthozoa: azooxanthellate Scleractinia from the Philippine and Indonesian regions. Mem Mus Natl Hist Nat 172:27-243

Cairns SD, Häussermann V, Försterrra G (2005) A review of the Scleractinia (Cnidaria: Anthozoa) of Chile, with the description of two new species. Zootaxa 1018:15-46

Daly M, Fautin DG (2008) Order Corallimorpharia. In: Zhang ZQ, Shear WA (eds) Linneaus tercentenary: progress in invertebrate taxonomy. Zootaxa 1668:139-140

> Daly M, Fautin DG, Cappola VA (2003) Systematics of the Hexacorallia (Cnidaria: Anthozoa). Zool J Linn Soc 139: 419-437

den Hartog JC (1980) Caribbean shallow water Corallimorpharia. Zool Verh 176:1-83

Dunn DF (1982) Cnidaria. In: Parker SP (ed) Synopsis and classification of living organisms, Vol 1. McGraw-Hill, New York, p 669-706

Ekman S (1953) Zoogeography of the sea. Sidgwick \& Jackson, London

Fautin DG (1984) More Antarctic and sub-Antarctic sea anemones (Coelenterata: Corallimorpharia and Actiniaria). Antarct Res Ser 41:1-42

Fautin DG (1989) Anthozoan dominated benthic environments. Proc 6th Int Coral Reef Symp 3:231-236

Fautin DG (2008) Hexacorallians of the world. Available at: http://geoportal.kgs.ku.edu/hexacoral/anemone2/index.cfm

Fautin DG, Lowenstein JM (1994) Phylogenetic relationships among scleractinians, actiniarians, and corallimorpharians (Coelenterata: Anthozoa). Proc 7th Int Coral Reef Symp 2:665-670

Fine M, Tchernov D (2007) Scleractinian coral species survive and recover from decalcification. Science 315:1811

Franz DR, Worley EK, Merrill AS (1981) Distribution patterns of common seastars of the middle Atlantic continental shelf of the northwest Atlantic (Gulf of Maine to Cape Hatteras). Biol Bull 160:394-418

Fukami H, Chen CA, Budd AF, Collins A and others (2008) Mitochondrial and nuclear genes suggest that stony corals are monophyletic but most families of stony corals are not (Order Scleractinia, Class Anthozoa, Phylum Cnidaria). PLoS One 3:e3222

> Goreau TF, Goreau NI (1959) The physiology of skeleton formation in corals. II. Calcium deposition by hermatypic corals under various conditions in the reef. Biol Bull 117: 239-250

Guinotte JM, Fabry VJ (2008) Ocean acidification and its potential effects on marine ecosystems. In: Ostfeld RS, 
Schlesinger WH (eds) The year in ecology and conservation biology 2008. Ann N Y Acad Sci 1134:320-342

Guinotte JM, Orr J, Cairns S, Freiwald A, Morgan L, George R (2006) Will human-induced changes in seawater chemistry alter the distribution of scleractinian bioherms? Front Ecol Environ 4:141-146

Hand C (1966) On the evolution of the Actiniaria. In: Rees WJ (ed) The Cnidaria and their evolution. Academic Press, London, p 135-146

Hertwig R (1882a) Die Actinien der Challenger Expedition. Gustav Fischer, Jena

Hertwig R (1882b) Report on the Actinaria dredged by H.M.S. Challenger during the years 1873-1876. In: Thomson CW, Murray J (eds) Report on the scientific results of the voyage of H.M.S. Challenger during the years 1873-76. Zoology, Vol 6, p 1-136

Hertwig R (1882c) Die Tiefseeactinien des Challenger. Jena Z Naturwiss 1881:10-13

Hertwig R (1885) The Actiniaria in narrative of the cruise. In: Thomson CW, Murray J (eds) Report on the scientific results of the voyage of H.M.S. Challenger during the years 1873-76. Zoology, Vol 1, p 574-576

Hertwig R (1888) Report on the Actiniaria dredged by H.M.S. Challenger during the years 1873-1876: supplement. In: Thomson CW, Murray J (eds) Report on the scientific results of the voyage of H.M.S. Challenger during the years 1873-76. Zoology, Vol 26, Part 73, p 1-56

Kleypas JA, Feely RA, Fabry VJ, Langdon C, Sabine CL, Robbins LL (2006) Impacts of ocean acidification on coral reefs and other marine calcifiers: a guide for future research. Report of a workshop held 18-20 April 2005, St. Petersburg, FL, sponsored by NSF, NOAA and US Geol Surv, available at http://www.ucar.edu/communications/Final_ acidification.pdf

Langmuir C (2004) Making waves. Nature 429:131

Medina M, Collins AG, Takaoka TL, Kuehl JV, Boore JL (2006) Naked corals: skeleton loss in Scleractinia. Proc Natl Acad Sci USA 103:9096-9100

Moseley HN (1876) Preliminary report to Professor Wyville Thomson, F.R.S., director of the civilian scientific staff, on the true corals dredged by H.M.S. 'Challenger' in deep water between the dates Dec. 30th, 1870, and August 31st,

Submitted: March 2, 2009; Accepted: August 14, 2009
1875. Proc R Soc Lond 24:544-569

Moseley HN (1877) On new forms of Actiniaria dredged in the deep sea; with a description of certain pelagic surfaceswimming species. Trans Linn Soc Ser 2 1:295-305

Moseley HN (1881) Report on certain hydroid, alcyonarian, and madreporarian corals procured during the voyage of H.M.S. Challenger during the years 1873-76. Part III. On deep-sea Madreporaria. In: Thomson CW, Murray J (eds) Report on the scientific results of the voyage of H.M.S. Challenger during the years 1873-76. Zoology, Vol 2, Part 1, p 127-208, 238-248

Orr JC, Fabry VJ, Aumont O, Bopp L and others (2005) Anthropogenic ocean acidification over the twenty-first century and its impact on calcifying organisms. Nature 437:681-686

Perry SM, Fautin DG (2004) Beginning with the Challenger. Ocean Challenge 13:4-6

Quelch JJ (1886) Report on the reef-corals collected by H.M.S. Challenger during the years 1873-76. In: Thomson CW, Murray J (eds) Report on the scientific results of the voyage of H.M.S. Challenger during the years 1873-76. Zoology, Vol 16, p 1-208

Rehbock PF (ed) (1992) At sea with the scientifics: the Challenger letters of Joseph Matkin. University of Hawaii Press, Honolulu, HI

Romano SL, Cairns SD (2000) Molecular phylogenetic hypotheses for the evolution of scleractinian corals. Bull Mar Sci 67:1043-1068

Sammarco PW (1982) Polyp bail-out: an escape response to environmental stress and a new means of reproduction in corals. Mar Ecol Prog Ser 10:57-65

> Scrutton C (1999) Palaeozoic corals: their evolution and palaeoecology. Geol Today 15:184-193

Stanley GD Jr, Fautin DG (2001) The origins of modern corals. Science 291:1913-1914

Thresher RE, MacRae CM, Wilson NC, Fallon S (2009) Feasibility of age determination of deep-water bamboo corals (Gorgonacea; Isididae) from annual cycles in skeletal composition. Deep-Sea Res I 56:442-449

Veron JEN (1995) Corals in space and time: the biogeography and evolution of the Scleractinia. University of New South Wales Press, Sydney

Proofs received from author(s): October 1, 2009 